\title{
LIBRARY AND INFORMATION SCIENCE GRADUATES \\ FROM SPAIN - \\ PROFESSIONAL TRAINING AND WORKFORCE ENTRY
}

\author{
Blanca Rodríguez Bravo \\ Doctora en Historia, Profesora Titular de Universidad \\ Universidad de León (España), blanca.rodriguez@unileon.es
}

\begin{abstract}
Professional training and workforce entry profiles of Library and Information Science graduates from Spain are analysed. For this purpose 105 alumni who had graduated from the Library and Information Science (LIS) Diploma course at the University of León between the years 1993 and 2007 were surveyed and the results analysed in order to identify further professional training undertaken, professional profiles, and professional career paths. These results were compared with those obtained from a series of interviews conducted with information professionals employed in León, and with results of another survey of professionals working in other regions in Spain. The aim was to improve the LIS degree curriculum at the University of León.
\end{abstract}

\section{INTRODUCTION}

In Spain - and in Europe in general - higher education is immersed in a process of change. Compliance with the Bologna Treaty has implied a structural revision involving the disappearance of the previous university qualifications of diploma holder and graduate, to be replaced by the qualifications of bachelor's degree and master's degree. In Spain, this has meant the gradual implementation of a four year Library and Information Science Degree, substituting for both the Library and Information Science Diploma (three years), taught since 1978, and the Information Science Degree (two years), taught since 1994.

At León University, the Library and Information Science Diploma course has been taught since the academic year 1990-1991. Given the impending disappearance of this diploma course, we felt it was appropriate to review the professional achievements of those students who have graduated in this subject at León University over the past fifteen academic years. 


\section{AIMS AND METHODOLOGY}

The aim of this research was to undertake an analysis of Library and Information Science Diploma graduates in terms of their further professional training, professional profiles, and professional career paths. The purpose was to improve the LIS degree curriculum at the University of León. Survey subjects comprised graduates from the past 15 academic years (1993-2007) at the University of León. Data were collected using a survey designed especially for this purpose and distributed to a random selection of 300 graduates. The survey was dispatched by post and/or electronic mail on the $29^{\text {th }}$ of February, 2008. By March 312008 , 105 completed questionnaires had been received, and graduates from all 15 academic years were represented among the replies.

The questionnaire was divided into 13 sections covering the following points:

- Sex

- Age

- Disability or special needs

- First course year and year of graduation

- Degree of satisfaction with the training provided by the University

- Employment status during Diploma studies

- Current professional employment status

- Years between graduation and entry into the workforce

- Professional activity following graduation: further education and training, job-seeking, preparation for public examinations, etc.

- Library and Information Science graduate professional training profiles

- Assessment of professional employment opportunities

- Evaluation of competences necessary to fulfil professional obligations, and level to which these were developed during University studies

- Personal employment history

At the same time, interviews were carried out with information professionals; specifically, those who had acted as supervisors for the obligatory work experience component (practicum) included in the Diploma and undertaken by students. These professionals were employed in León at the following institutions: the Municipal Archive, the Provincial Historical Archive, the Public Library, the University Library, the MUSAC (a museum of art) Library, the Caja de España (a bank) Information Centre, the Editorial Everest Archive, and the Hullera Vasco-Leonesa (an energy company) Information Centre (La Robla).

Likewise, the opinions of prestigious professionals working outside the province of León were collected using a structured questionnaire. From a total of 25 questionnaires sent to information professionals selected for their diverse profiles, 17 were completed and returned: 6 were received from university or specialist library directors, 4 from archive directors, 3 from public library directors, 2 from 
documentalists, 1 from a project director and 1 from the director of an information services company.

The questionnaire was divided into the following sections:

- Name

- Company

- Post

- Location

- University qualifications

- Company or institution information: Status, Sphere of Influence, Sector and Number of employees

- Number of Library and Information Science graduates employed by the company

- Principal criteria applied when employing Diploma holders

- Professional training profiles for Library and Information Science graduates

- Evaluation of competences necessary to fulfil professional obligations, and graduate proficiency in performance of professional duties

- Suggestions for improvement

It should be noted that the competences established in both questionnaires were an adaptation of the European Council of Information Associations guide "Competencies and aptitudes for European information professionals." 1

Both questionnaires are included in the appendices.

\section{DIPLOMA GRADUATE SURVEY RESULTS}

With regard to demographic data, it should be noted that there was a wide age range among the 105 respondents, and that over $80 \%$ were women. This latter fact reflects the customary predominance of women among the Library and Information Science Diploma student body.

Regarding entry into the workforce, we are able to supply the following data. In response to the question concerning students' employment status whilst studying, 40 graduates replied that they had combined paid work with their studies, and 25 of these had been working in jobs related to their studies. In contrast, 65 graduates replied that they had concentrated exclusively on studying. Given that some graduates had not sought employment immediately following their graduation, they were asked if they had studied for public examinations or had undertaken further study. Of the 105 Diploma holders, 38 replied that they had entered the Information Science Degree programme.

In an assessment of professional career opportunities, $2 \%$ replied "a lot," $28 \%$ "quite a lot," 50\% "some," and 20\% "few." In terms of years between graduation and employment, of the 61 replies obtained, 18 respondents cited less than a year, 24 said 1 year, 14 replied 2 or 3 years, and 5 responded over 3 years. 
Of the graduates who completed the questionnaire $80 \%$ are currently employed in posts related to the field of information and documentation: 32 are employed without a contract, with a grant (scholarships); 63 in the public sector; and 27 in private companies.

The public sector is also the main employer in the results of a survey sent in 2006 to the associates of the Spanish Society for Scientific Information (Sociedad Española de Documentación Científica-SEDIC), the main association for the information sector in Spain. ${ }^{2}$

In the section concerning personal employment history, the majority of graduates who completed this section mentioned having been employed on scholarships or on temporary work experience contracts

Respondents felt that the Diploma had provided adequate preparation for professional employment as an archivist, a librarian, a documentalist, a corporate information manager in private companies; and secondarily as an expert in information literacy (teaching basics of information technologies), a digital content manager, and a media information manager.

Concerning competences necessary to fulfil professional obligations and the level to which these were developed during university studies, all the competences listed were highly rated, with a predominant score of $4 / 5$ on a scale of 1 (minimum) to 5 (maximum). The perceived importance of the competences was rated more highly than was the graduates' achievement as a result of studies, with a predominant score of 3 .

Competences perceived to be of highest value were related to global management of information, information search and retrieval techniques, elaboration and dissemination of information, information and communication technologies, and modern languages. Likewise, interpersonal skills were also highly rated, that is, interaction with clients and service users, institutional communication and relations, creativity and adaptability, etc. The observed results are similar to those of the project directed by Moreiro. ${ }^{3}$

\section{PROFESSIONALS INTERVIEW AND SURVEY RESULTS}

Interviews and surveys of professionals yielded the following opinions:

When contracting a Library and Information Science graduate, the main criterion considered was their university education. Only professionals working in private companies or specialised institutions gave more weight to specialised training or specific practical skills related to the particular post in question, and to the candidate's ability to adapt to the working environment.

In terms of graduates' professional training profiles, there was general agreement that current training primarily prepares students for employment as librarians and documentalists, and to a lesser extent, as archivists and information literacy experts. Preparation for employment as digital content managers, media informa- 
tion managers, corporate information managers and cultural consultants, and managers was considered secondary.

Turning to the competences necessary to fulfil professional obligations, and graduate proficiency in performing professional duties, the professionals surveyed agreed with the graduates' positive evaluation of the 23 competences listed, with a predominance of scores equal to or over 4 on a scale of 1 (minimum) to 5 (maximum). With regard to an assessment of graduates' proficiency in performing professional duties, scores were slightly lower.

In particular, the most highly valued competences were those related to information search and retrieval techniques, management and organisation of information, information and communications technology, modern languages, and interpersonal and communication skills both within the organisation and with clients. The professionals and academics at the meeting held in León confirmed the same view. ${ }^{4}$

\section{DISCUSSION}

Despite the bias-which we are aware may exist-arising from the fact that those most inclined to complete the questionnaire were the graduates currently in employment, it is nevertheless possible to confirm a high rate of entry into the professional workforce. The situation is confirmed as well by the results of the survey sent to the Spanish Society of Documentation and Scientific Information (SEDIC) associates. $^{2}$

Time taken to obtain a first post was not prolonged, although it is also true that graduates felt obliged to accept scholarship posts or temporary work experience posts for longer than was reasonable. This same workforce entry situation for Library and Information Science graduates has been reported in the majority of studies carried out in Spain.

Most graduates are employed in traditional posts: archivists, librarians, documentalists; these are the most highly rated professional profiles, especially that of librarian. Graduates working in the public sector predominate, although a significant percentage of graduates are also employed as documentalists and/or corporate information managers in private companies.

Table I: Importance of the competences

\begin{tabular}{|l|c|c|c|c|}
\hline COMPETENCES & I.-G. & LDU $-\boldsymbol{G}$. & $\boldsymbol{I}$.-P & $\boldsymbol{L D U}-\boldsymbol{P}$ \\
\hline Information search and retrieval & 5 & 3 & 5 & 5 \\
Interaction with service users and clients & 5 & 3 & 5 & 4 \\
Knowledge of the profession & 4 & 2 & 5 & 3 \\
Information and communication & 5 & 3 & 5 & 3
\end{tabular}




\section{technologies}

Management, administrative, economics and marketing techniques

Project and planning management techniques

Content analysis and information organisation

Digitization and electronic media Identification and assessment of information

Global information management

Information management techniques (cataloguing, etc.)

Elaboration and dissemination of information

Collection management

Production and publication techniques

Document preservation (storage, restoration, conservation, etc.)

Teaching skills

Knowledge of the business world

Institutional interpersonal skills

Oral and written communication

Team skills

Creativity and adaptation in problem solving

Modern languages

Interpersonal communication skills

Other (please specify)

\begin{tabular}{|c|c|c|c|}
\hline 4 & 2 & 4 & 2 \\
\hline 4 & 2 & 4 & 2 \\
\hline 5 & 3 & 5 & 5 \\
\hline 5 & 2 & 4 & 3 \\
\hline 5 & 3 & 5 & 5 \\
\hline 5 & 3 & 5 & 4 \\
\hline 5 & 4 & 4 & 4 \\
\hline 5 & 3 & 5 & 3 \\
\hline 5 & 4 & 5 & 4 \\
\hline 4 & 2 & 3 & 3 \\
\hline 5 & 4 & 3 & 3 \\
\hline 3 & 2 & 4 & 3 \\
\hline 4 & 2 & 4 & 1 \\
\hline 4 & 2 & 4 & 3 \\
\hline 4 & 3 & 5 & 4 \\
\hline 5 & 3 & 5 & 4 \\
\hline 5 & 3 & 4 & 3 \\
\hline 5 & 3 & 5 & 3 \\
\hline 4 & 3 & 4 & 4 \\
\hline
\end{tabular}

I.-G. Importance for Graduates LDU-G. Level of Development at University for Graduates

I.-P. Importance for Professionals LDU-G. Level of Development at University for Professionals

The fact that all the competences listed are highly rated is a reflection of the versatility of the Library and Information Science Diploma qualification. This finding has also been reported in other, similar, studies, such as that carried out by Tejada Artigas and Rodríguez Yunta, comprising the first survey of members of SEDIC in $2001 .^{5}$ 
Nevertheless, the level of proficiency achieved by graduates in these competences was always awarded a slightly lower score, and the same result is observed when professionals are questioned on graduates' proficiency in competences at work. However, professionals are more positive in their score than graduates. We feel that the new study plans, designed in accordance with European Space for Higher Education guidelines, ${ }^{6}$ which place greater emphasis on "know how," will help to redress this imbalance.

Those surveyed and interviewed were united in specifying the need to prioritise student training in information skills, especially computer management skills, and also emphasised the need to possess a good operational command of English and a working knowledge of the world of private business. Almost all the speakers at the meeting hold in León in October 2008 insist on the necessity of a better command of computer skills as well as of communicative skills, both in Spanish and English. $^{4}$

The new Library and Information Degree course designed and proposed by the University of León promotes the acquisition of the competences in question. Competences related to information searching, retrieval, management and organisation, prioritised by the survey respondents, will represent a significant proportion of the subjects proposed in the new degree course. Similarly, information technology skills and knowledge concerning the world of private business will be consolidated via the introduction of various core, obligatory, and elective courses. Finally, we feel that it is essential for students to have good operational control of English. We start from the assumption that students enter their degree course with an intermediate level of English, and the aim will be to promote English language courses at an advanced level that would be eligible for elective course credits.

\section{REFERENCES}

1. European Council of Information Associations (ECIA). Euroguide LIS. Volume 1, Competencies and aptitudes for European information professionals. $2^{\text {nd }}$ entirely revised ed. 2004. http://www.certidoc.net/en/euref1-english.pdf (accessed 31 May 2009).

2. Tejada Artigas C, Rodríguez Yunta L (2007). Un acercamiento a la situación laboral y desarrollo profesional de los trabajadores de la información y documentación: la encuesta SEDIC 2006. In: $10^{a}$ Jornadas Españolas de Documentación: El profesional en el entorno digital. Santiago de Compostela: Fesabid, 2007. http://eprints.rclis.org/9825/ (accessed 31 May 2009).

3. Moreiro González JA. Construcción de un sistema para la definición de perfiles profesionales y de competencias de formación para estudiantes de Información y Documentación: estudio comparativo para Brasil y España. Proyecto subvencionado por el Ministerio de Educación español dentro del Programa Hispano-Brasileño de Cooperación Interuniversitaria. 2005-2008. 
4. Rodríguez Bravo B. Encuentro de académicos, estudiantes y profesionales de la información en la Universidad de León. El Profesional de la Información, en.-feb. 2009; 18(1):95-105.

5. Tejada Artigas, C., Rodríguez Yunta, L. Sistematización de competencias de los profesionales de la información. Valoración de la relación de Decidoc por los asociados de Sedic. El Profesional de la Información, en.-feb. 2003;12(1):10-7.

6. European Association for Quality Assurance in Higher Education (ENQA). Standards and guidelines for quality assurance in the European higher education area. Helsinki: ENQA, 2005. http://www.eua.be/fileadmin/user_upload/ files/Quality_Assurance/ESG.pdf(accessed 31 May 2009).

\section{APPENDIX I: GRADUATE SURVEY}

INTRODUTION: The aim of this questionnaire is to gather information from graduates on competences and entry into the workforce, in order to design the Library and Information Science Degree course study plan. We appreciate your cooperation, and guarantee the anonymity of all replies received.

Date: $29^{\text {th }}$ of February, 2008.

INSTRUCTIONS: please indicate your reply below with an " $\mathrm{X}$ ". In some cases, you will be asked to choose between "yes" and "no", and in others, to indicate your level of agreement (from 1 to 5 , where 5 indicates highest level of agreement). Should you wish to change a reply, please circle the incorrect response, and mark a different box.

\begin{tabular}{|l|l|}
\hline $\begin{array}{l}\text { Sex: } \\
\text { Male } \square \text { Female } \square\end{array}$ & $\begin{array}{l}\text { Age } \\
\square 21-25 \square 26-30 \square 31-35 \square 36-40 \square+41\end{array}$ \\
\hline First course year & Year of graduation \\
\hline $\begin{array}{l}\text { Degree of satisfaction with the education and training received at the Uni- } \\
\text { versity: } \\
\text { Very } \square \text { Reasonably } \square \text { Quite } \square \text { Not very } \square \text { Not at all } \square\end{array}$ \\
\hline $\begin{array}{l}\text { Please mark your employment status during your university studies: } \\
\square \text { Full-time student } \square \text { Employment related to studies } \square \text { Employment unrelated to } \\
\text { studies }\end{array}$ \\
\hline Present Professional situation & $\square$ \\
\hline Continuing education & $\square$ \\
\hline Employment related to studies
\end{tabular}




\begin{tabular}{|l|l|}
\hline Employment unrelated to studies & $\square$ \\
\hline Seeking first post & $\square$ \\
\hline Currently unemployed, but have worked previously & $\square$ \\
\hline Unemployed, not seeking work & $\square$ \\
\hline Other & $\square$ \\
\hline
\end{tabular}

How many years did it take following graduation to find your first post? (Only applicable if employed in a post related to studies)

After Graduation ... (Mark an " $\mathrm{X}$ " in as many boxes as necessary)

\begin{tabular}{|l|l|}
\hline I sought employment & $\square$ \\
\hline $\begin{array}{l}\text { I enrolled on the Library and Information Science Degree } \\
\text { course }\end{array}$ & $\square$ \\
\hline I enrolled on another degree or diploma course & $\square$ \\
\hline I enrolled on a Master's degree course & $\square$ \\
\hline I enrolled on a Doctorate course, DEA or thesis & $\square$ \\
\hline I obtained another grant & $\square$ \\
\hline I studied for public examinations & $\square$ \\
\hline I undertook further training related with my Diploma & $\square$ \\
\hline I undertook further training in the new technologies & $\square$ \\
\hline I studied modern languages & $\square$ \\
\hline Other (please specify) & $\square$ \\
\hline A graduate in Librarv and Inormation Studies is cagable
\end{tabular}

A graduate in Library and Information Studies is capable of fulfilling the following professional posts

\begin{tabular}{|l|l|}
\hline Archivist & Yes $\square$ No $\square$ \\
\hline Cultural consultant and manager & Yes $\square$ No $\square$ \\
\hline Librarian & Yes $\square$ No $\square$ \\
\hline Documentalist & Yes $\square$ No $\square$ \\
\hline Non-university teacher & Yes $\square$ No $\square$ \\
\hline University lecturer & Yes $\square$ No $\square$ \\
\hline Information literacy expert & Yes $\square$ No $\square$ \\
\hline Digital content manager & Yes $\square$ No $\square$ \\
\hline Media information manager & Yes $\square$ No $\square$ \\
\hline
\end{tabular}




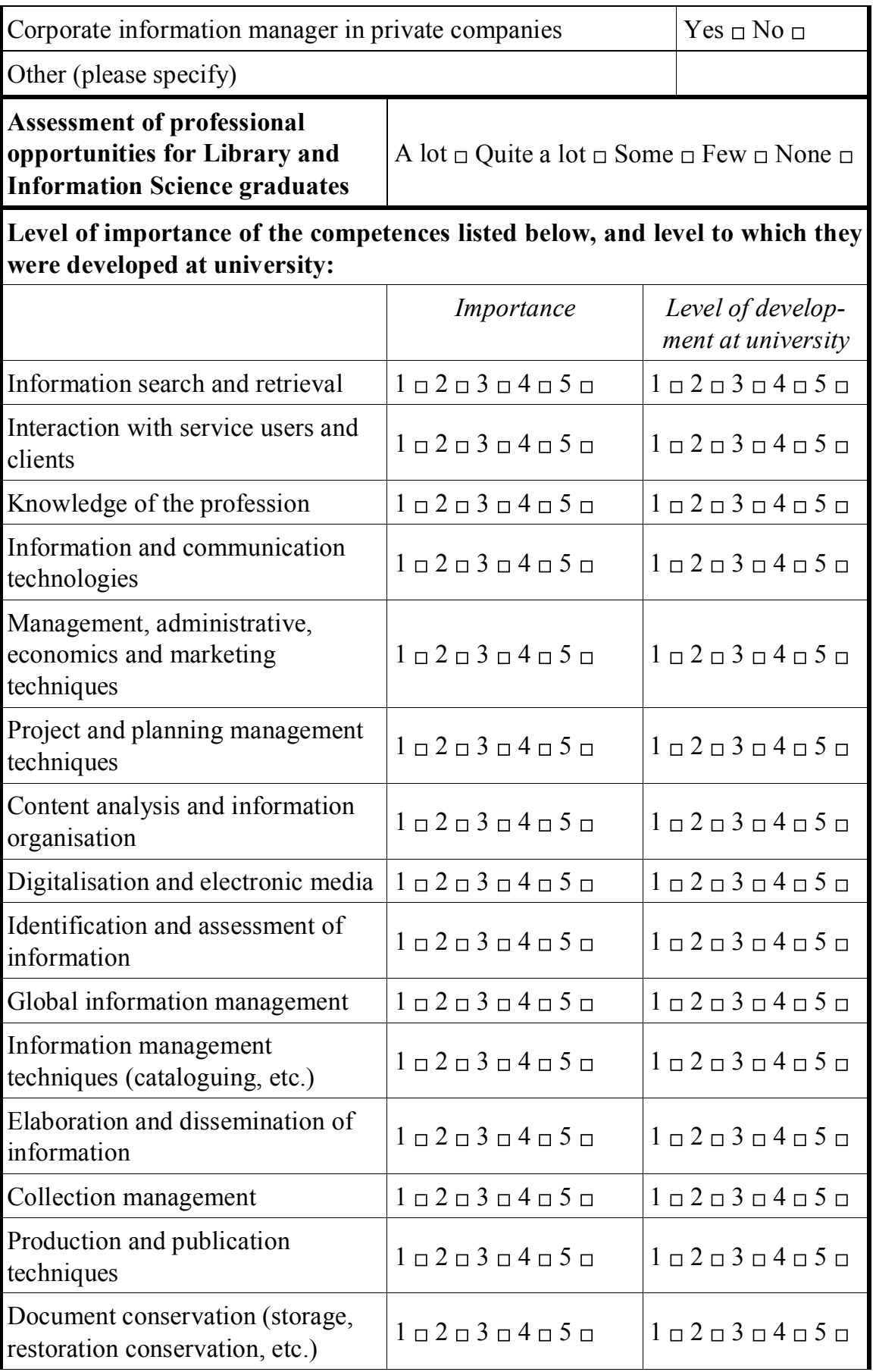




\begin{tabular}{|c|c|c|}
\hline Teaching skills & $1 \square 2 \square 3 \square 4$ 口 5 व & $1 \square 2 \square 3 \square 4 \square 5 \square$ \\
\hline $\begin{array}{l}\text { Knowledge of the world of } \\
\text { business }\end{array}$ & $1 \square 2 \square 3 \square 4 \square 5 \square$ & $1 \square 2 \square 3 \square 4 \square 5 \square$ \\
\hline Institutional interpersonal skills & $1 \square 2 \square 3 \square 4 \square 5 \square$ & $1 \square 2 \square 3 \square 4 \square 5 \square$ \\
\hline Oral and written communication & $1 \square 2 \square 3 \square 4 \square 5 \square$ & $1 \square 2 \square 3 \square 4 \square 5 \square$ \\
\hline Team skills & $1 \square 2 \square 3 \square 4 \square 5 \square$ & $1 \square 2 \square 3 \square 4 \square 5 \square$ \\
\hline $\begin{array}{l}\text { Creativity and adaptation in } \\
\text { problem solving }\end{array}$ & 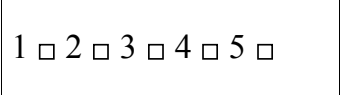 & $1 \square 2 \square 3 \square 4 \square 5 \square$ \\
\hline Modern languages & 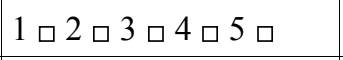 & $1 \square 2 \square 3 \square 4 \square 5 \square$ \\
\hline Interpersonal communication skills & $1 \square 2 \square 3 \square 4 \square 5 \square$ & $1 \square 2 \square 3 \square 4 \square 5 \square$ \\
\hline Other (please specify) & $1 \square 2 \square 3 \square 4 \square 5 \square$ & $1 \square 2 \square 3 \square 4 \square 5 \square$ \\
\hline \multicolumn{3}{|c|}{$\begin{array}{l}\text { Personal employment history following graduation (Please list posts held re- } \\
\text { lated to the Diploma) }\end{array}$} \\
\hline \multicolumn{3}{|l|}{ Special needs } \\
\hline \multicolumn{2}{|c|}{$\begin{array}{l}\text { Did you suffer any disability whilst studying for the } \\
\text { Diploma? }\end{array}$} & Sí $\square$ No $\square$ \\
\hline \multicolumn{2}{|c|}{ If yes to the above, did you receive support? } & Sí $\square$ No $\square$ \\
\hline \multicolumn{3}{|c|}{ If yes to the above, what kind of support did you receive? } \\
\hline \multicolumn{2}{|c|}{ Did you need more support than was offered? } & Sí $\square$ No $\square$ \\
\hline \multicolumn{3}{|l|}{ If yes to the above, please specify } \\
\hline \multicolumn{2}{|c|}{$\begin{array}{l}\text { Did you need special educational support whilst studying } \\
\text { for the Diploma? }\end{array}$} & Sí $\square$ No $\square$ \\
\hline \multicolumn{2}{|c|}{ If yes to the above, did you receive support? } & Sí $\square$ No $\square$ \\
\hline \multicolumn{3}{|c|}{ If yes to the above, what kind of support did you receive? } \\
\hline \multicolumn{2}{|c|}{ Did you need more support than was offered? } & Sí $\square$ No $\square$ \\
\hline
\end{tabular}




\section{APPENDIX II: PROFESSIONALS SURVEY}

INTRODUCTION: The aim of this questionnaire is to gather information from professionals on competences and entry into the workforce, in order to design the Library and Information Science Degree course study plan. We appreciate your co-operation, and guarantee the anonymity of all replies received.

\section{Date: $\quad 29^{\text {th }}$ of February, 2008.}

INSTRUCTIONS: please indicate your reply below with an "X". In some cases, you will be asked to choose between "yes" and "no", and in others, to indicate your level of agreement (from 1 to 5 , where 5 indicates highest level of agreement). Should you wish to change a reply, please circle the incorrect response, and mark a different box.

\begin{tabular}{|l|l|}
\hline Name: & Company: \\
\hline Post: & Location: \\
\hline $\begin{array}{l}\text { Qualifications (if different from the University Library and Information } \\
\text { Science qualifications listed below) }\end{array}$ \\
\hline $\begin{array}{l}\text { Diploma in Library and } \\
\text { Information Science }\end{array}$ & $\square$ \\
\hline $\begin{array}{l}\text { Degree in Library and } \\
\text { Information Science }\end{array}$ & $\square$ \\
\hline Doctorate or Master's degree & $\square$ \\
\hline Other Diplomas & $\square$ \\
\hline Other Degrees & $\square$ \\
\hline Other Qualifications & $\square$ \\
\hline Company or institution information \\
\hline Status & $\square$ Public $\square$ Private $\square$ Mixed \\
\hline Sphere of influence & $\begin{array}{l}\text { National } \square \text { Autonomous region } \square \text { Provincial } \square \\
\text { Municipal }\end{array}$ \\
\hline Sector: & $\begin{array}{l}\text { Library } \square \text { Historic archives } \square \text { Administrative } \\
\text { archives } \square \\
\text { General documentation centre } \square \text { Specialised } \\
\text { documentation centre } \square \\
\text { Company archives } \square \text { Cultural institution } \square \\
\text { Consultancy } \square \text { Outreach services } \square \text { Educational } \\
\text { centres } \square \text { Other (please specify) }\end{array}$ \\
\hline Number of employees & $\square 1-5 \square 6$-15 $\square$ 16-30 $\square 31-50 \square+51$ \\
\hline
\end{tabular}


Has your institution or company contracted a Library and Information Science graduate recently?

Yes $\square$ No $\square$

Please indicate the importance of the following criteria when contracting a Library and Information Science graduate

\begin{tabular}{|l|l|}
\hline & Importance \\
\hline $\begin{array}{l}\text { University training received during the Diploma } \\
\text { course }\end{array}$ & $1 \square 2 \square 3 \square 4 \square 5 \square$ \\
\hline $\begin{array}{l}\text { University training received on the } \\
\text { Degree/Postgraduate course }\end{array}$ & $1 \square 2 \square 3 \square 4 \square 5 \square$ \\
\hline $\begin{array}{l}\text { Specialist training related to a specific post in } \\
\text { your institution or company }\end{array}$ & $1 \square 2 \square 3 \square 4 \square 5 \square$ \\
\hline $\begin{array}{l}\text { Specific practical skill related to a particular } \\
\text { post in your institution }\end{array}$ & $1 \square 2 \square 3 \square 4 \square 5 \square$ \\
\hline Adaptability to the working environment & $1 \square 2 \square 3 \square 4 \square 5 \square$ \\
\hline Other (please specify) & $1 \square 2 \square 3 \square 4 \square 5 \square$ \\
\hline
\end{tabular}

A graduate in Library and Information Studies is capable of fulfilling the following professional posts

\begin{tabular}{|l|l|}
\hline Archivist & Yes $\square$ No $\square$ \\
\hline Cultural consultant and manager & Yes $\square$ No $\square$ \\
\hline Librarian & Yes $\square$ No $\square$ \\
\hline Documentalist & Yes $\square$ No $\square$ \\
\hline Non-university teacher & Yes $\square$ No $\square$ \\
\hline University lecturer & Yes $\square$ No $\square$ \\
\hline Information literacy expert & Yes $\square$ No $\square$ \\
\hline Digital content manager & Yes $\square$ No $\square$ \\
\hline Media information manager & Yes $\square$ No $\square$ \\
\hline $\begin{array}{l}\text { Corporate information manager in private } \\
\text { companies }\end{array}$ & Yes $\square$ No $\square$ \\
\hline Other (please specify) & \\
\hline
\end{tabular}




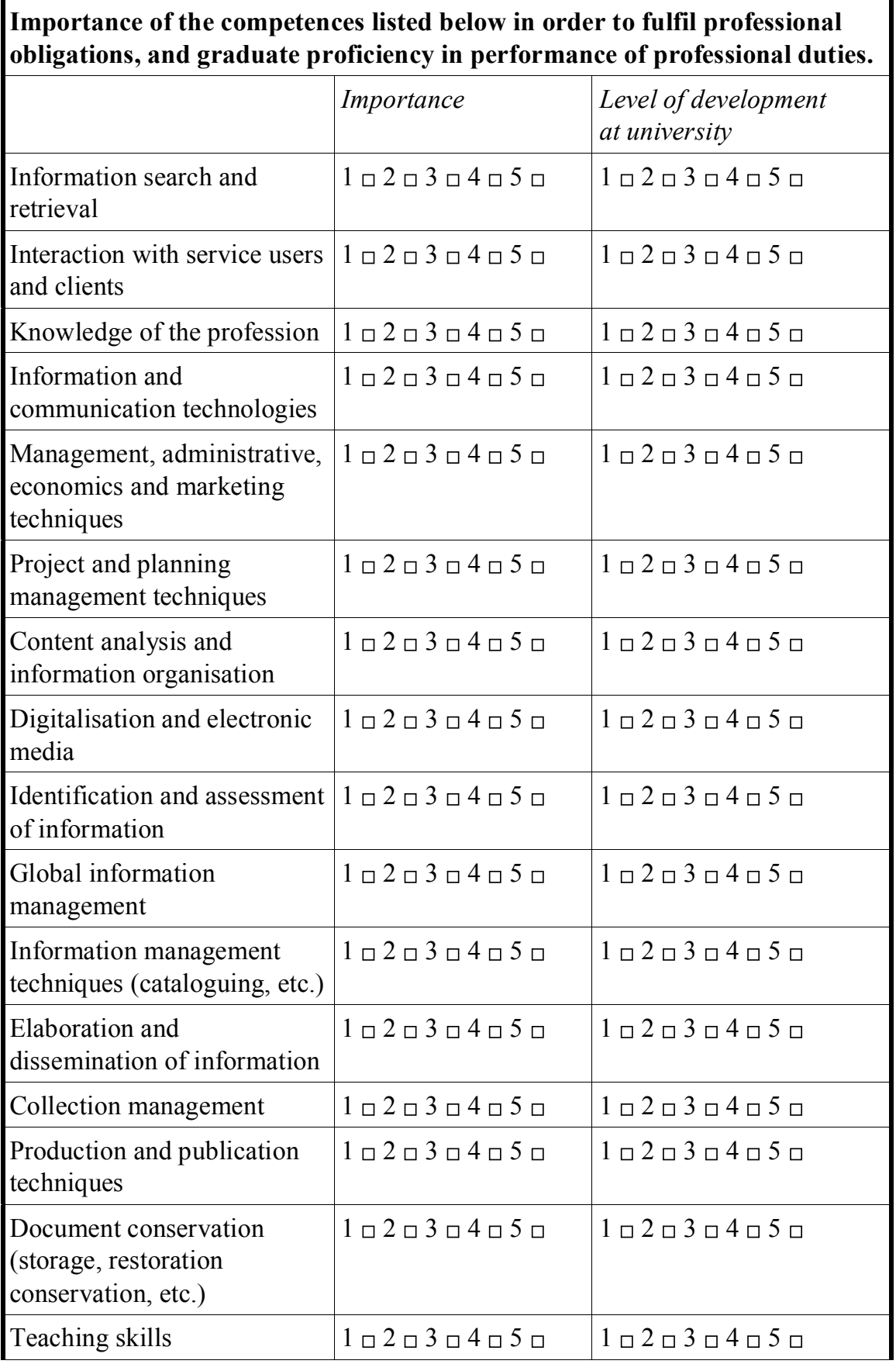




\begin{tabular}{|c|c|c|}
\hline $\begin{array}{l}\text { Knowledge of the world of } \\
\text { business }\end{array}$ & $1 \square 2 \square 3 \square 4 \square 5 \square$ & 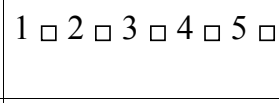 \\
\hline $\begin{array}{l}\text { Institutional interpersonal } \\
\text { skills }\end{array}$ & $1 \square 2 \square 3 \square 4 \square 5 \square$ & $1 \square 2$ 口 3 口 4 口 5 \\
\hline $\begin{array}{l}\text { Oral and written } \\
\text { communication }\end{array}$ & $1 \square 2 \square 3 \square 4 \square 5 \square$ & 1 口 2 口 3 口 4 口 5 \\
\hline Team skills & $1 \square 2 \square 3 \square 4 \square 5 \square$ & 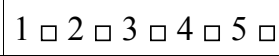 \\
\hline $\begin{array}{l}\text { Creativity and adaptation in } \\
\text { problem solving }\end{array}$ & $1 \square 2 \square 3 \square 4 \square 5 \square$ & 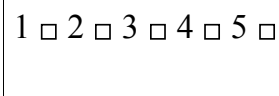 \\
\hline Modern languages & $1 \square 2 \square 3 \square 4 \square 5 \square$ & 1 口 2 口 3 口 4 口 5 \\
\hline $\begin{array}{l}\text { Suggestions for } \\
\text { improvement }\end{array}$ & & \\
\hline
\end{tabular}

